\title{
Anti-ICAM-1 Monoclonal Antibody BI-505
}

National Cancer Institute

\section{Source}

National Cancer Institute. Anti-ICAM-1 Monoclonal Antibody BI-505. NCI Thesaurus.

Code C88327.

A fully human IgG1 monoclonal antibody directed ag ainst intercellular adhesion molecule-

1 (ICAM-1 or CD54), with potential antineoplastic activity. Anti-ICAM-1 monoclonal antibody $\mathrm{BI}-505$ selectively binds to the adhesion protein ICAM-1, which may result in antibody-dependent cellular cytotoxicity (ADCC), hyper-cross-linking-induced apoptosis, and a decrease in cellular proliferation of ICAM-1-expressing tumor cells. ICAM-1, normally expressed on leukocytes and endothelial cells, may be overexpressed in a variety of cancers. 